\title{
X Rays Treated Leguminous Seeds in Combination with Wild Plant Powder for the Promotion of Growth and Control of Root Rot Fungi
}

\author{
Naheed Ikram¹, Shahnaz Dawar ${ }^{1 *}$ and Fauzia Imtiaz ${ }^{2}$
}

${ }^{1}$ Department of Botany, University of Karachi, Pakistan

${ }^{2}$ Department of Biochemistry, Dow University of Health sciences, Karachi, Pakistan

\begin{abstract}
Present research work was designed to investigate the $\mathrm{x}$ rays treated leguminous seeds in combination with Prosopis juliflora Swartz in the suppression of root rot fungi. Seeds of cowpea and mungbean were treated with x-rays at 45 and 75 kiloelectron volt (keV) for 5,10 and 20 sec and soil was amended with Prosopis juliflora leaves powder @1\%. Both leguminous crops showed significant increase in all growth parameters and reduction in infection of root rot fungi viz., Fusarium spp., Rhizoctonia solani and Macrophomina phaseolina. Complete reduction of Rhizoctonia solani and Macrophomina phaseolina was observed when seeds were treated with $45 \mathrm{keV}$ for 5,10 and $20 \mathrm{sec}$. and soil was amended with Prosopis juliflora leaves powder @1\%. There was significant increase in all growth parameters when seeds of both leguminous crops exposed with x-rays for $5 \mathrm{sec}(45 \mathrm{keV})$
\end{abstract}

Keywords: X-rays; Prosopis leaves powder; Soil amendment; Leguminous seeds

\section{Introduction}

$\mathrm{X}$-rays are a form of electromagnetic radiation, just like light waves and radio waves. Because X-rays have higher energy than light waves, they can pass through the body. X-rays were first discovered over 100 years ago and were quickly applied to medical diagnostic use. Today $\mathrm{x}$-rays remain a valuable tool in diagnosis and treatment of many injuries and diseases. Radiation considered being an excellent tool for sterilization, preservation of food and other different food engineering processes, which gives benefit to the human society [1-3]. Effects of radiation on plants are a broad and complex field and work is being done in many areas on a large number of plant species. Radiation affects the size and weight of plants. There is variety of control methods used in order to avoid the yield losses due to soil borne pathogens such as use of radiations [4], chemical compounds which are toxic to fungi [5]. X-ray is commonly used to observe and quantify the soil environment including plant root development [6-8] fungal influence $[9,10]$, changes to pore structure $[11]$ and the influence of microbial activity [12].

$\mathrm{X}$-ray dose influence on plant root growth $[6,13]$, fungal [9] or microbial activity [14]. The influence of X-ray dose on plants and animals is under studies [15], Stuppy et al. [16] studied that repeated exposure of $\mathrm{x}$-ray was not feasible for living system. Dutilleul et al. stated that repeated exposure of $\mathrm{x}$-ray is not suitable for living organisms and particularly plants. Dose is the quantity of energy absorbed by an object after exposure to radiation [13,17]. Many x-ray studies provide insufficient information on impact of $\mathrm{x}$-ray dose on plant growth and microbial activity [18].

Irradiation of soil could influence microbial communities through the direct ionization of cells causing DNA mutation, and the indirect radiolysis of cell water creating damaging free radicals within extra- and intra-cellular fluids [19]. Free radicals can cause single or double stranded DNA breaks [20], damaging future cell and plant development. The impact of X-ray radiation on soil constituents, much of the focus being based on $\gamma$-rays due to its application in soil sterilization procedures. Responses to radiation continually change as enzymatic activity in soils aid recovery from acute doses, although sensitivity is dependent on a large range of physiological factors such as metabolic activity, organism size and complexity, and life-cycle stage [20]. A dose of $10 \mathrm{~Gy}$ of $\mathrm{X}$-ray radiations is equivalent to $10 \mathrm{~Gy}$ of $\gamma$-ray radiation since $\mathrm{X}$-rays and $\gamma$-rays have the same radiation weighting factor, formerly known as quality factor, which is a measure of the expected biological impact of ionizing radiation often used in radiation protection [21]. Rhizoctonia solani (Kiihn) and Fusarium spp. cause wilting of different crop plants. Wilt has become a major disease causing significant reduction in yield.

Root rot fungi viz., Macrophomina phaseolina (Tassi) Goid, Rhizoctonia solani (Kiihn) and Fusarium spp., cause wilting of different plants. Wilting is characterized by yellowing of foliage, drooping of apical shoot to ultimate death of whole plant. The pathogen is a soil inhabiting fungus and forms in the senescing tissues of the diseased plant and may survive in the soil for many years. There are many methods which are presently being used to control various plant pathogens including wilt pathogens. Disease causing organisms which adversely affect the crop productivity like charcoal rot fungus Macrophomina phaseolina has a very wide host range and attacks the root and basal stem [22]. Mostly disease causing organisms are soil borne pathogens viz., Macrophomina phaseolina (Tassi) Goid, Rhizoctonia solani (Kiihn) and Fusarium spp., attack roots limiting nutrition uptake resulting in the death of plants $[23,24]$.

Prosopis juliflora is a shrub belonging to the Mimosaceae family. $P$. juliflora has astringent, antiseptic, antibacterial and antifungal properties $[25,26]$. The extracts of $P$. juliflora seeds and leaves were well studied for several in vitro pharmacological effects such as antibacterial [27], antifungal $[28,29]$ and anti-inflammatory properties $[28,30]$. These properties have been attributed to piperidine alkaloids [31]. The main alkaloids including the juliflorine and julifloricine of $P$. juliflora were isolated by Ahmad et al. [32] and their antibacterial and antifungal activities have also been reported $[33,34]$. The flavonoid patulitrin isolated from its flowers and fruits showed significant activity

*Corresponding authors: Shahnaz Dawar, Department of Botany, University of Karachi, Pakistan, Tel: +92 21 99261300; E-mail: shahnaz_dawar@yahoo.com

Received May 27, 2015; Accepted June 22, 2015; Published June 26, 2015

Citation: Ikram N, Dawar S, Imtiaz F (2015) X Rays Treated Leguminous Seeds in Combination with Wild Plant Powder for the Promotion of Growth and Control of Root Rot Fungi. J Plant Pathol Microbiol S3: 003. doi:10.4172/2157-7471.S3-003

Copyright: @ $2015 \mathrm{lkram} \mathrm{N}$, et al. This is an open-access article distributed under the terms of the Creative Commons Attribution License, which permits unrestricted use, distribution, and reproduction in any medium, provided the original author and source are credited. 
against lung carcinoma in vivo [35]. Ikram and Dawar [36] reported that Prosopis juliflora stem and leaves powder@ 0.1 and 1\% were found effective for the enhancement of plant height and weight of cowpea and mungbean.

The aim of present research work was to find out the effect of $\mathrm{x}$-rays treated seeds and P. juliflora leaves powder in the control of root rot fungi and on growth of cowpea and mungbean.

\section{Methodology}

\section{Collection of material}

Prosopis juliflora leaves were collected from University of Karachi campus air dried and ground in a grinder.

\section{Exposure of seeds to radiation}

Seeds of cowpea (Vigna unguiculata) mung bean (Vigna radiata L.) were exposed to $\mathrm{x}$-rays of 45 and $75 \mathrm{keV}$ at time periods of 5, 10 and $20 \mathrm{sec}$. The seeds were irradiated at the Pakistan laboratory Karachi, Pakistan.

\section{Physical properties of soil}

Soil used was obtained from experimental plot of Department of Botany, University of Karachi. The sandy loam soil containing (sand, silt, clay, 60, 22 \& 18\%), pH ranged from 7.1-7.5 with moisture holding capacity (MHC) of 29\% [37], total nitrogen 0.077-0.099\% [38], 3-4 sclerotia/g of M. phaseolina g-1as found by wet sieving technique [39], $5-10 \%$ of R. solani on sorghum seeds used as baits [40] and Fusarium spp.,3500 cfu g-1 as assessed by soil dilution technique [41].

\section{Experimental setup}

The irradiated and non-irradiated seeds were sown in $8 \mathrm{~cm}$ diam., plastic pots, and each containing $300 \mathrm{~g}$ soil and watered regularly to maintain sufficient moisture required for the growth of plants. The pots were kept in screen house in randomized complete block design with three replicates per treatment. Non treated seeds served as control. Soil amendment with P. juliflora leaves powder @ 1\% w/w and leaves it for one week to decompose. Growth parameter of control and irradiated seedlings were recorded after 30 days of seed germination.

\section{Determination of root infecting fungi}

To determine the incidence of root rot fungi, one $\mathrm{cm}$ long root pieces after washing in running tap water were surface sterilized with $1 \% \mathrm{Ca}(\mathrm{OCl})_{2}$ and transferred on PDA plates supplemented with Penicillin@200 mg/L and streptomycin@ 200mg/ L. Petri dishes were incubated at room temperature $\left(28^{\circ} \mathrm{C}\right)$ and after one week colonization of root infecting fungi was recorded.

\section{Statistical analysis}

Data were subjected to analysis of variance (ANOVA) followed by the least significant difference (LSD) test at $\mathrm{P}=0.05$ and Duncan's multiple range test to compare treatment means, using statistics software according to Sokal \& Rohlf (1995).

\section{Results}

\section{Mungbean}

There was significant $(\mathrm{P}<0.01)$ increase in germination, shoot weight and root length when seeds of mungbean treated with $\mathrm{x}$-rays for $5 \mathrm{sec}$ at $45 \mathrm{keV}$ as compared to 10 and $20 \mathrm{sec}$. Leaf area and no. of nodules significantly $(\mathrm{P}<0.001)$ increased when seeds were treated with
$\mathrm{X}$-rays for $20 \mathrm{sec}$ at $45 \mathrm{keV}$ as compared with control. $100 \%$ germination $(\mathrm{P}<0.001)$ was observed when mungbean seeds were treated with x-rays (45 and 75keV) for 5, 10 and $20 \mathrm{sec}$. and soil was with P. juliflora leaves powder @1\%. Mungbean plants showed significant $(\mathrm{P}<0.001)$ increased in length, fresh weight of root, leaf area and no. of nodules when seeds of mungbean exposed on $\mathrm{x}$-rays $(45 \mathrm{keV})$ for $5 \mathrm{sec}$ and soil amended with $P$. juliflora leaves powder @1\%. Shoot weight was significantly $(\mathrm{P}<0.01)$ increased when seeds of mungbean treated with $\mathrm{X}$-rays $(45 \mathrm{Kev})$ for $20 \mathrm{sec}$ and was soil amended with P. juliflora leaves powder @1\%. Root length was significantly increased $(\mathrm{P}<0.05)$ when seeds irradiated with $\mathrm{x}$-rays $(45 \mathrm{Kev})$ for $5 \mathrm{sec}$ and soil amended with leaves powder (Figure 1).

Effect of $\mathrm{x}$-rays and soil amendment with $P$. juliflora leaves powder $@ 1 \%$ caused significant reduction $(\mathrm{P}<0.001)$ in the infection of root rot fungi like, Fusarium spp., Rhizoctonia solani and Macrophomina phaseolina. Colonization of all root infecting fungi completely suppressed when seeds were treated with $\mathrm{x}$-rays at 5, 10 and $20 \mathrm{sec}$ and soil amendment with $P$. juliflora leaves (Figure 2).

\section{Cowpea}

After 30 days of germination, cowpea roots showed significant $(\mathrm{P}<0.001)$ reduction in colonization of root rot fungi. Colonization of Fusarium spp., Rhizoctonia solani and Macrophomina phaseolina were completely suppressed when cowpea seeds treated with $\mathrm{X}$-rays at 5, 10 and $20 \mathrm{sec}$ and soil was amendment with $P$. juliflora leaves and germination, leaf area and no. of nodules significantly $(\mathrm{P}<0.001)$ increased when cowpea seeds exposed to $\mathrm{x}$-rays $(45 \mathrm{keV})$ for 5 and 10 sec than control and amended soil. Fresh weight of shoot and root significantly $(\mathrm{P}<0.01)$ increased when seeds were exposed to $\mathrm{x}$-rays for $5 \mathrm{sec}(45 \mathrm{keV})$ (Figure 2).

There was significant increase $(\mathrm{P}<0.01)$ in growth when seeds of cowpea were treated with $\mathrm{x}$-rays and soil was amended with $P$. juliflora leaves powder@1\%. Shoot length increased $(34.66 \mathrm{~cm})$ when seeds were treated with $\mathrm{x}$-rays $(45 \mathrm{keV})$ for $5 \mathrm{sec}$ and soil amended with $P$. juliflora leaves as compared to control $(11 \mathrm{~cm})$. Shoot and root weight significantly increased $(\mathrm{P}<0.01)$ when seeds exposed to $\mathrm{x}$-rays $(45$ $\mathrm{keV}$ ) for $10 \mathrm{sec}$. and soil mix with P. juliflora leaves @1\%. There was significant increase $(\mathrm{P}<0.001)$ in rot length, leaf area and no. of nodules when seeds were treated with $\mathrm{x}$-rays $(45 \mathrm{keV})$ for $5 \mathrm{sec}$. in combination with amended soil (Figure 3).

\section{Discussion}

Exposure of mungbean and cowpea seeds treated with x-rays (45kv) for $5 \mathrm{sec}$. and soil amendment with $P$. juliflora leaves powder showed significant increase in all growth parameters such as plant length and weight leaf area and no of nodules. Similarly Dawar et al., [42] observed that soil drenching with T. harzianum, R. meliloti and $P$. aeruginosa and seeds of sunflower, mung bean were exposed with gamma rays $\left({ }^{60} \mathrm{Co}\right)$ at $0,2,8$ and 16 min., interval completely reduced the infection of R. solani, M. phaseolina and Fusarium spp. Thapa [43] reported that root, hypocotyl, and epicotyl elongation decreases as the exposure time increases. Present results supported by Thapa [44] that germination and seedling growth of Pinus kesiya Gord and $P$. wallichiana A.B. Jacks were inhibited with the increased in exposure of gamma rays $\left({ }^{60} \mathrm{CO}\right)$ whereas in some cases the lower exposure was stimulatory. Irradiation of mungbean seeds with gamma rays $\left({ }^{60} \mathrm{Co}\right)$ for 0 and 4 minutes enhance the growth parameters in terms of shoot length, shoot weight, root length, root weight, leaf area and reduce the infection of root infecting fungi [45]. 

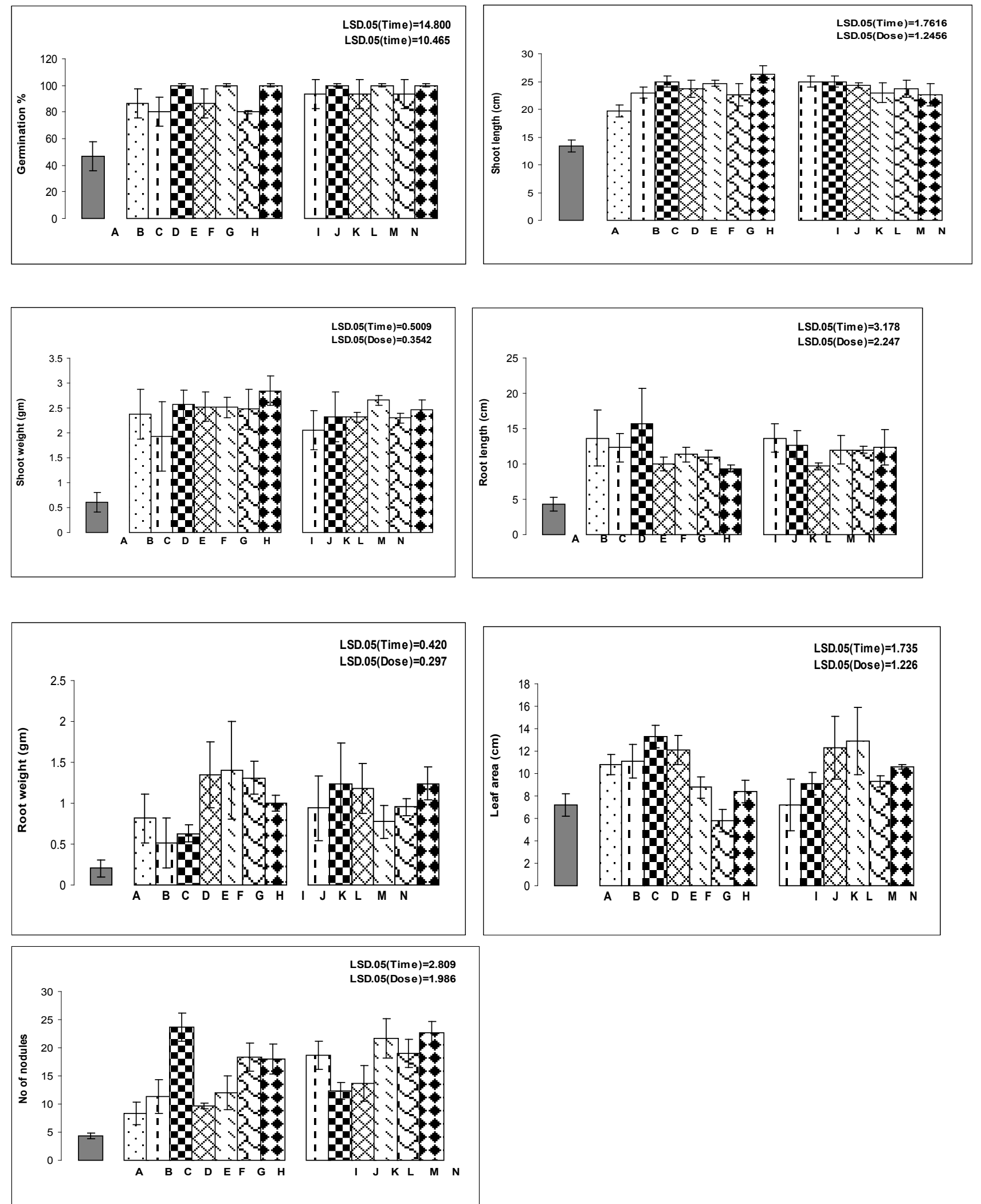

Figure 1: Effect of X-rays in combination with Prosopis juliflora leaves powder @1\% w/w on growth parameters of mung bean. A=control, B=Prosopis leaves@1\%, $\mathrm{C}=5 \mathrm{sec}(45 \mathrm{Kev}) \mathrm{D}=5 \mathrm{Sec}(45 \mathrm{keV})+$ Prosopis leaves@1\% E=10sec (45 keV) F=10 Sec (45 keV)+Prosopis leaves@1\% G=20sec (45 Kev) H=20 Sec (45 Kev)+Prosopis leaves@1\% I=5sec $(75 \mathrm{keV}) \mathrm{J}=5 \mathrm{Sec}(75 \mathrm{Kev})+$ Prosopis leaves@1\% K=10sec $(75 \mathrm{keV}) \mathrm{L}=10 \mathrm{Sec}(75 \mathrm{keV})+$ Prosopis leaves@1\% M=20sec (75 keV) N=20 Sec (75 keV)+Prosopis leaves@1\%. 
COWPEA
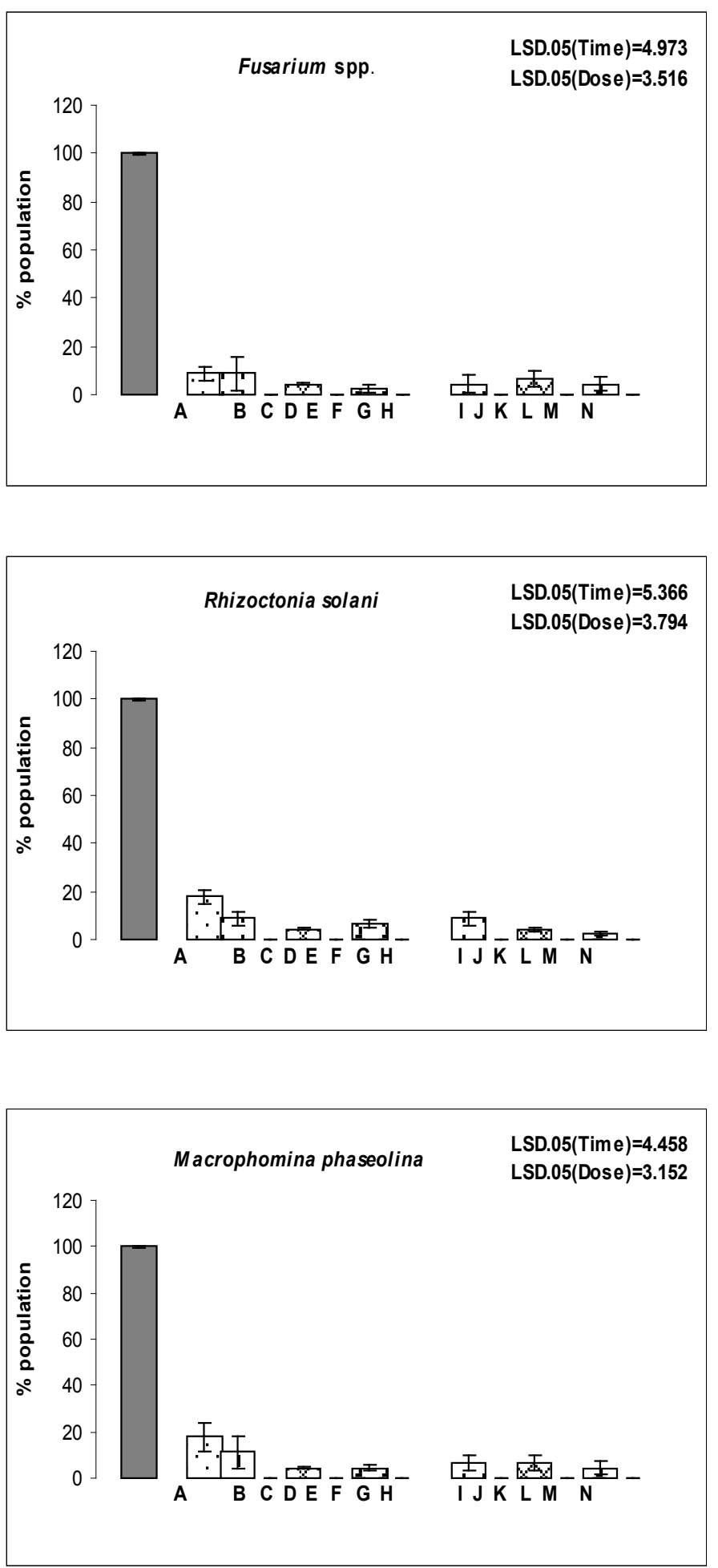

MUNGBEAN
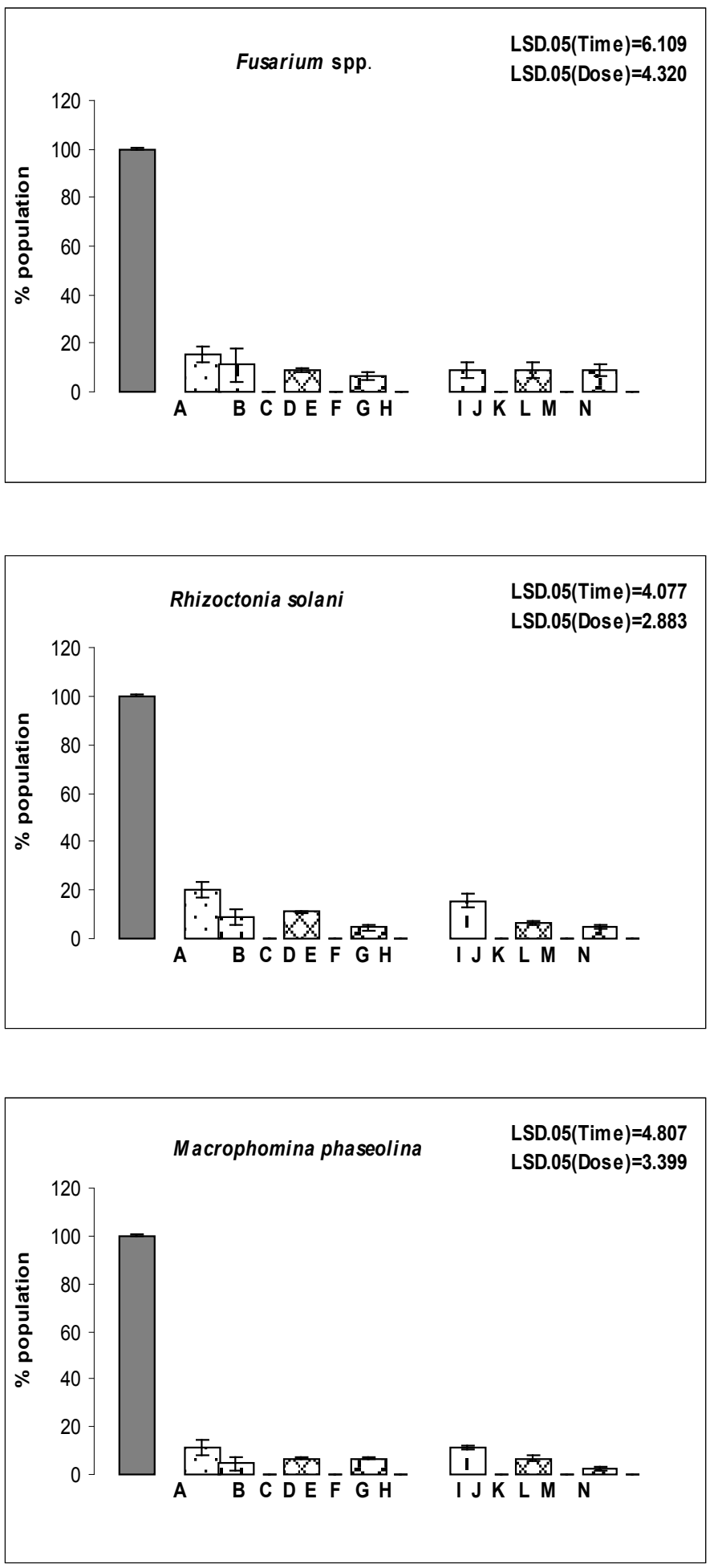

Figure 2: Effect of X-rays in combination with Prosopis juliflora leaves powder @1\% w/w on root rot fungi of cowpea and mung bean. A=control, B=Prosopis leaves@1\%, C=5sec (45Kev) D=5 Sec (45 keV)+Prosopis leaves@1\% E=10sec (45 keV) F=10 Sec (45 keV)+Prosopis leaves@1\% G=20sec (45 Kev) H=20 Sec $(45 \mathrm{Kev})+$ Prosopis leaves@1\% I=5sec $(75 \mathrm{keV}) \mathrm{J}=5 \mathrm{Sec}(75 \mathrm{Kev})+$ Prosopis leaves@1\% K=10sec $(75 \mathrm{keV}) \mathrm{L}=10 \mathrm{Sec}(75 \mathrm{keV})+$ Prosopis leaves@1\% M=20sec $(75$ $\mathrm{keV}) \mathrm{N}=20 \mathrm{Sec}(75 \mathrm{keV})+$ Prosopis leaves@1\%. 

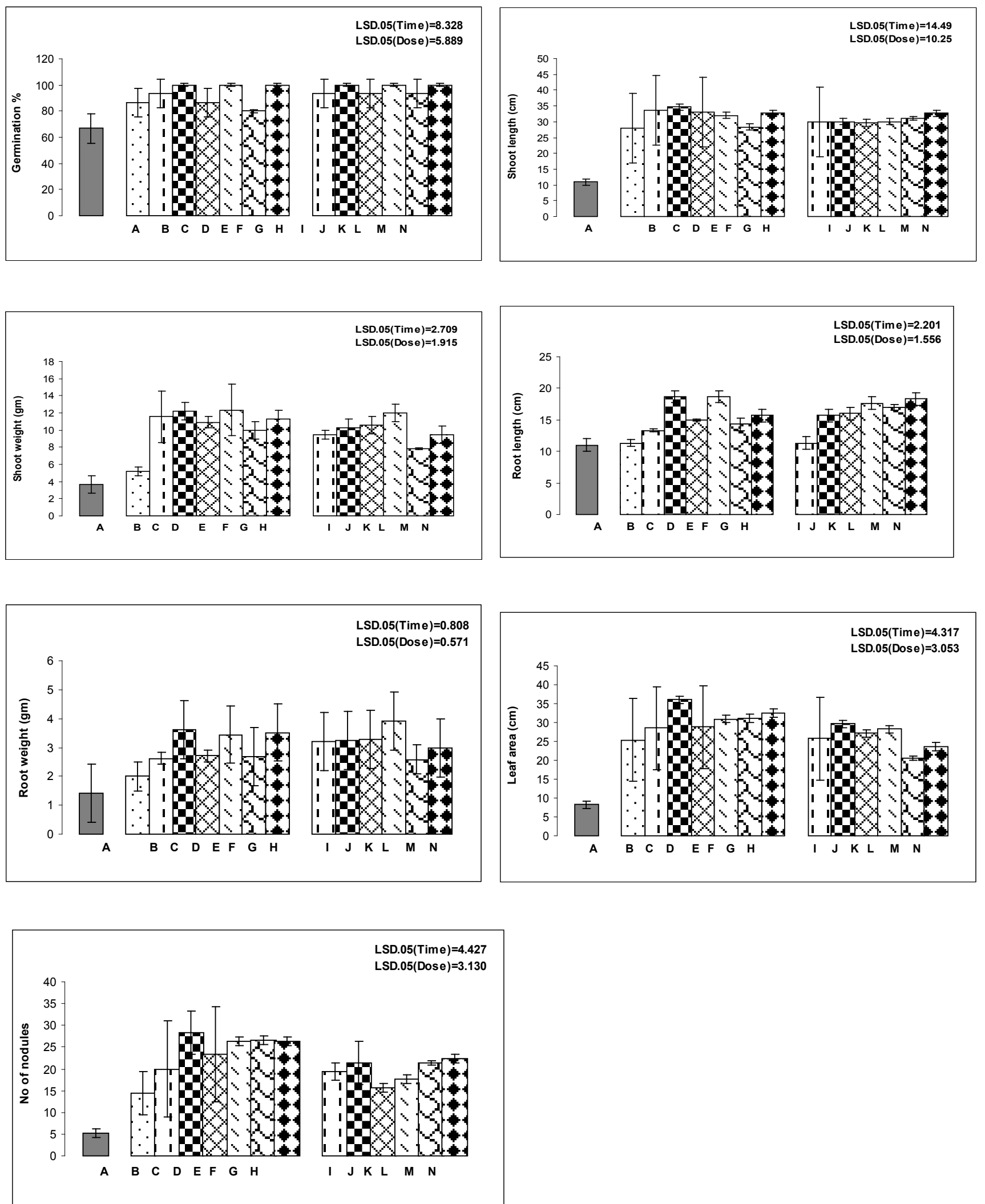

Figure 3: Effect of $\mathrm{X}$-rays in combination with Prosopis juliflora leaves powder @1\% w/w on growth parameters of cowpea. A=control, B=Prosopis leaves@1\%, $\mathrm{C}=5 \mathrm{sec}(45 \mathrm{Kev}) \mathrm{D}=5 \mathrm{Sec}(45 \mathrm{keV})+$ Prosopis leaves@1\% E=10sec (45 keV) F=10 Sec (45 keV)+Prosopis leaves@1\% G=20sec (45kv) H=20 Sec (45 Kev)+Prosopis leaves@1\% I=5sec $(75 \mathrm{keV}) \mathrm{J}=5 \mathrm{Sec}(75 \mathrm{Kev})+$ Prosopis leaves@1\% K=10sec $(75 \mathrm{keV}) \mathrm{L}=10 \mathrm{Sec}(75 \mathrm{keV})+$ Prosopis leaves@1\% M=20sec $(75 \mathrm{keV})$ N=20 Sec $(75$ keV)+Prosopis leaves@1\%. 
Citation: Ikram N, Dawar S, Imtiaz F (2015) X Rays Treated Leguminous Seeds in Combination with Wild Plant Powder for the Promotion of Growth and Control of Root Rot Fungi. J Plant Pathol Microbiol S3: 003. doi:10.4172/2157-7471.S3-003

There was complete suppression of root rot fungi when seeds were treated with x-rays for 5, 10 and $20 \mathrm{sec}$. and soil was amended with $P$. juliflora leaves powder @1\%. Present results were supported by Jackson et al., [19] demonstrated that fungi are more sensitive to radiation than bacteria, with $\gamma$-irradiation doses $10 \mathrm{~Gy}$ able to alter fungal populations. $\mathrm{Al}$ Khayri et al. [46] found relatively small X-ray exposures of 0.25 Gy had an influence on biochemical aspects of date palm (Phoenix dactylifera $L$.) development i.e. DNA and pigment synthesis.

There was significant increase in all growth parameters when seeds of both leguminous crops exposed with $\mathrm{x}$-rays for $5 \mathrm{sec}(45 \mathrm{keV})$. Whereas Zappala et al. [47] reported that X-ray CT does not impact on plant growth and soil microbial populations when employing a low level of dose ( $<30 \mathrm{~Gy})$.

Recently several works has explored that $\mathrm{x}$-rays can be used to sterilize various foodstuffs to inactivate microbial contamination $[48,49]$.

Many biomedical research facilities handling pathogenic agents assist in the identification of possible safety threats and reduce the crossborder traffic in dangerous materials with the help of $\mathrm{x}$-irradiation. $\mathrm{X}$-irradiation has provided a useful model for examining the effects of ionizing radiation on survival and repairs the genetic damage in microbial systems [50-57].

\section{Conclusion}

Present result suggested that low dose of x-rays treated and amended soil with $P$. juliflora leaves powder induce stimulated effect on plants and reduced the root rot fungi. So, experiment would be carried out on large scale for obtaining good yield of crops.

\section{References}

1. Ivanov AS, Ovchinnikov VP, Svinin MP, Tolstun NG, Bogart SL (2001) $4 \mathrm{MeV}$ highvoltage acelerator with $500 \mathrm{~kW}$ electron beam for radiation sterilization. Vacuum 62: 225-231.

2. Song HP, Kim DH, Jo C, Lee $\mathrm{CH}$, Kim KS, et al. (2006) Effect of gamma irradiation on the microbiological quality and antioxidant activity of fresh vegetable juice. Food Microbiol 23: 372-378.

3. Sameh ASA, Kumar AP, Rao BS, Singh RP (2006) Biodegradation of $y$-sterilised biomedical polyolefins under composting and fungal culture environments. Poly Degrad Stab 91: 1105-1116.

4. Spadaro D, Gullino ML (2005) Improving the efficacy of biocontrol agents against soilborne pathogens. Crop Prot 24: 601-613.

5. Washington WS, McGee P (2000) Dimethomorph soil and seed treated of potted tomatoes for control of damping off and root rot caused by Phytophthora nicotianae var. micotianae. Austr PI Pathol 29: 46-51.

6. Flavel RJ, Guppy CN, Tighe M, Watt M, McNeill A, et al. (2012) Non-destructive quantification of cereal roots in soil using high-resolution X-ray tomography. $J$ Exp Bot 63: 2503-2511.

7. Karahara I, Umemura K, Soga Y, Akai Y, Bando T (2012) Demonstration of osmotically dependent promotion of aerenchyma formation at different levels in the primary roots of rice using a 'sandwich'method and X-ray computed tomography. Annals of Botany 110: 503-509.

8. Tracy SR, Black C, Roberts J, McNeill A, Davidson R (2012) Quantifying the effect of soil compaction on three varieties of wheat (Triticum aestivum L.) using X-ray Micro Computed Tomography (CT). Plant and Soil 353: 195-208.

9. Kravchenko A, Falconer RE, Grinev D, Otten W (2011) Fungal colonization in soils with different management histories: modeling growth in three-dimensional pore volumes. Ecological Applications 21: 1202-1210.

10. Martin SL, Mooney SJ, Dickinson MJ, West HM (2012) The effects of simultaneous root colonisation by three Glomus species on soil pore characteristics. Soil Biology and Biochemistry 49: 167-173.

11. Munkholm LJ, Heck RJ, Deen B (2012) Soil pore characteristics assessed from
X-ray micro-CT derived images and correlations to soil friability. Geoderma 181-182: 22-29

12. Nunan N, Ritz K, Rivers M, Feeney DS, Young IM (2006) Investigating microbia micro-habitat structure using X-ray computed tomography. Geoderma 133: 398-407.

13. Gregory PJ, Hutchison DJ, Read DB, Jenneson PM, Gilboy WB (2003) Noninvasive imaging of roots with high resolution X-ray micro-tomography. Plant and Soil 255: 351-359.

14. Bouckaert L, Van Loo D, Ameloot N, Buchan D, Van Hoorebeke L (2012) Compatibility of X-ray micro-Computed Tomography with soil biological experiments. Soil Biology and Biochemistry 56: 10-12.

15. Yang W, Xu X, Duan L, Luo Q, Chen S, et al. (2011) High-throughput measurement of rice tillers using a conveyor equipped with $\mathrm{x}$-ray computed tomography. Rev Sci Instrum 82: 025102.

16. Stuppy WH, Maisano JA, Colbert MW, Rudall PJ, Rowe TB (2003) Threedimensional analysis of plant structure using high-resolution $\mathrm{X}$-ray computed tomography. Trends Plant Sci 8: 2-6.

17. Johnson EL (1936) Effects of X-rays upon green plants: Biological effects of radiation, (1stedn), McGraw-Hill Book Company Inc, New York: 961-985.

18. Stupian GW (2007) X-Ray Dose in Microfocus Radiographic Inspections, Aerospace Corp. El Segundo Ca Electronics Research Lab.

19. Jackson NE, Corey JC, Frederick LR, Picken JC (1967) Gamma Irradiation and the Microbial Population of Soils at Two Water Contents. Soil Sci Soc Am J 31: 491-494.

20. McNamara NP, Black HIJ, Beresford NA, Parekh NR (2003) Effects of acute gamma irradiation on chemical, physical and biological properties of soils. Applied Soil Ecology 24: 117-132.

21. Als-Nielsen J, McMorrow D (2011) Elements of modern X-ray physics (2ndedn), Wiley.

22. Sackston WE (1981) The sunflower crop and disease progress problems and prospects. Plant Disease 65: 643-648.

23. Booth C (1971) The genus Fusarium. Commonwealth Mycological Institute Kew, Surrey, England. 237

24. Nelson PE, Toussoun TE, Marasas W (1983) Fusarium species, An Illustrated Manual for identification. The Pennsylvania State University Press, University Park and London. 193

25. Ahmad A, Ahmad V, Khalid SM, Siddiqui SA, Khan KA (1995) Study of the antibacterial therapeutic efficacy of juliflorine, julifloricine and a benzene insoluble alkaloidal fraction of Prosopis juliflora. J Islamic Acad Sci 8: 131-136.

26. Kay MA (1996) Healing with plants in the American and Mexican West, Tuscon, The University of Arizona Press 221-224.

27. Aqeel A, Khursheed AK, Viqaruddin A, Sabiha Q (1989) Antimicrobial activity of julifloricine isolated from Prosopis juliflora. Arzneimittelforschung 39: 652-655.

28. Ahmad VU, Sultana A, Qazi S (1989b) Alkaloids from the leaves of Prosopis juliflora. J Nat Prod 52: 497-501.

29. Kaushik JC, Sanjay A, Tripathi NN (2002) Antifungal properties of some plan extracts against the damping-off fungi of forest nurseries. Indian J For 25: 359361.

30. Ahmad A, Khursheed AK, Sabiha Q, Viqaruddin A (1989a) Antifungal activity of some hydrosoluble Prosopis juliflora alkaloids. Fitoterapia 60: 86-89.

31. Ahmad A, Khan KA, Ahmad VU, Qazi S (1986) Antibacterial activity of juliflorine isolated from Prosopis juliflora. Planta Med 285-288.

32. Ahmad VU, Basha A, Haque W (1978) New alkaloids from Prosopis juliflora DC. Z Naturforsch 33: 347-348.

33. Khan KA, Faruqi AH, Rasool SA, Ahmad VU Qazi S, Haroon TS (1986) ArzeimForsch/Drug Res 36: 17.

34. Ragavendra MP, Satish S, Raveesha KA (2009) Alkaloids isolated from leaves of Prosopis juliflora against Xanthomonas pathovars. Arch of Phytopathol Plant Protection 42: 1033-1041.

35. Wassel GM, Rizk AM, Abdel-Bary EF (1972) Phytochemical investigation of Prosopis juliflora D.C.I. Flavonoids and free sugars. Plant Foods for Hum Nutri 22: $119-121$. 
Citation: Ikram N, Dawar S, Imtiaz F (2015) X Rays Treated Leguminous Seeds in Combination with Wild Plant Powder for the Promotion of Growth and Control of Root Rot Fungi. J Plant Pathol Microbiol S3: 003. doi:10.4172/2157-7471.S3-003

36. Ikram N, Dawar S (2013) Effect of Prosopis juliflora (Swartz,) DC. In the control of root rot fungi of cowpea (Vigna unguiculata L.) and mung bean (Vigna radiate L.). Pak J Bot 45: 649-654.

37. Keen BA, Raczkowski H (1992) The relation between clay content and certain physical properties of soil. J Agric Sci 11: 441-449.

38. Mackanzie HA, Wallace HS (1954) The Kjeldahl determination of nitrogen A critical study of digestion conditions, temperature, catalyst and oxidizing agents. Aust J Chem 7: 55-70.

39. Sheikh AH, Ghaffar A (1975) Population studies of sclerotia of Macrophomina phaseolina in cotton field. Pak J Bot 7: 13-17.

40. Wilhelm S (1955) Longevity of the Verticillium wilt fungus in the laboratory and field. Phytopathol. 45: 180-181.

41. Nash, SM, Snyder WC (1962) Quantitative estimation by plate count of propagules of the bean root rot fungus Fusarium in field soils. Phytopathol 52 : 567-572.

42. Dawar S, Zaki SM, Ikram N, Tariq M (2010) Gamma Radiation (60Co) Exposure and Application of Antagonists for the Suppression of Root Ro Diseases in Sunflower (Helianthus annus L.) and Mung Bean (Vigna radiata (L.) R. Wilczek). Our Nature 8: 26-33.

43. Thapa CB (2004) Effect of acute exposure of gamma rays on seed germination and seedling growth of Pinus kesiya Gord and P. wallichiana A.B. Jacks. Our Nature 2: 13-17.

44. Thapa CB (1999) Effect of acute exposure of gamma rays on seed germination Pinus kesiya Gord and P. wallichiana A.B. Jacks. Bot Orient J PI Sci 1: 120121.

45. Ikram N, Dawar S, Abbas Z, Zaki MJ (2010) Effect of (60 Cobalt) gamma rays on growth and root rot diseases in mungbean (Vigna radiate L.). Pak J Bot 42: 2165-2170.

46. Al-Khayri J, Al-Enezi N, Al-Bahrany A (2012) Effect of X-irradiation on date palm seed germination and seedling growth. Emirates Journal of Food and Agriculture 24: 415-424.

47. Zappala S, Helliwell JR, Tracy SR, Mairhofer S, Sturrock CJ, et al. (2013)
Effects of X-Ray Dose On Rhizosphere Studies Using X-Ray Computed Tomography. PLoS One 8: e67250.

48. Mahmoud BS (2010) Effects of x-ray radiation on Escherichia coli O157:H7 Listeria monocytogeneses,Salmonella enterica andShigella flexneri inoculated on shredded iceberg lettuce. Food Microbiology 27: 109-114.

49. Mahmoud BS, Bachman G, Linton RH (2010) Inactivation of Escherichia col O157:H7, Listeria monocytogenes, Salmonella enterica and Shigella flexneri on spinach leaves by X-ray. Food Microbiol 27: 24-28.

50. Bonura T, Youngs DA, Smith KC (1975) R.b.e. of $50 \mathrm{k} \mathrm{Vp} \mathrm{x-rays} \mathrm{and} 660 \mathrm{keV}$ gamma-rays (137 Cs) with respect to the production of DNA damage, repair and cell-killing in Escherichia coli K-12. Int J Radiat Biol Relat Stud Phys Chem Med 28: 539-548.

51. Driedger AA, James AP, Grayston MJ (1970) Cell survival and X-ray-induced DNA degradation in Micrococcus radiodurans. Radiat Res 44: 835-845.

52. Johansen I, Gulbrandsen R, Pettersen R (1974) Effectiveness of oxygen in promoting $x$-ray-induced single-strand breaks in circular phage lambda DNA and killing of radiation sensitive mutants of Escherichia coli. Radiation Research 58: 384-397.

53. Youngs DA, Smith KC (1976) The yield and repair of x-ray-induced singlestrand breaks in the DNA of Escherichia coli K-12 cells. Radiat Res 68: 148154

54. Yardin MR, Kennedy IR, Thies JE (2000) Development of high quality carrie materials for field delivery of key microorganisms used as bio-fertilisers and bio-pesticides. Radiation Physics and Chemistry 57: 565-568.

55. Al-Enezi NA, Al-Khayri JM (2012) Alterations of DNA, ions and photosynthetic pigments content in date palm seedlings induced by X-irradiation. Int J Agric Biol 14: 329-336.

56. Ahmad A, Khan KA, Ahmad VU (1991). Toxicological studies of antimicrobial alkaloid juliflorine. Arzneim-Forsch/Drug Res. 41: 151-154.

57. Johnson EL (1937) Tuberization of the Colorado wild potato as affected by X-radiation. Plant Physiology 12: 547.
This article was originally published in a special issue, Pathological Findings in Plants handled by Editor(s). Dr. Chioma Okeoma, Department of Microbiology University of lowa, USA 